\title{
Problems and Challenges of Girl-Child Education in Nigeria: The Situation of Kalgo Local Government Area (L.G.A) Of Kebbi State.
}

\author{
Tyoakaa, Lazarus Mvendaga, Amaka, John Ifeanyichukwu And Nor, Apine \\ Government Science \& Technical College Bunza, Kebbi State-Nigeria.
}

\begin{abstract}
The importance of girl-child education cannot be over emphasized. Hence, this study therefore examined the problems and challenges of girl-child education in kebbi state, with particular reference to Kalgo local government area. The study adopted a descriptive survey research design. The population for the study comprised of all the fifty one (51) primary schools and four (4) secondary schools in Kalgo L.G.A. However, a sample of fourteen (14) primary and two (2) secondary schools was randomly drawn from each of the fourteen communities. Two research questions were formulated, while data collection was majorly through the use of archival data such, checklist/inventory and oral interviews, and analyzed using simple descriptive statistics and tables. The study revealed that, the problems facing girl-child education in Kebbi state is not far from poverty, early marriage, cultural and religious misconceptions. The study recommends among other things that, government, non-governmental organizations, parents, traditional and religious leaders should join hands in the enlightment campaign for the benefits and need to educate a girl-child.
\end{abstract}

\section{Introduction}

The term 'girl-child' refers to a female between the ages of 6-18 years (Mukhtar et al., 2011). The National Child Welfare Policy (1989) as cited by Ada (2001) defines the girl-child as a female below 14 years of age. Offorma (2009) defines it as a biological female offspring from birth to eighteen (18) years of age. This period is made up of infancy, childhood, early and late adolescence stages of development. The girl-child is seen as a young female person who would eventually grow into a woman and marry. The gender apartheid places the girl-child in a disadvantaged position, where her potentials are suppressed and self-actualization is not achieved. She therefore, becomes a victim of a pre-existing socio-cultural male chauvinism. Furthermore, on the account of gender, girl-children are subjected to all multiple forms of oppression, exploitation and discrimination.

Girl-child education has then become a major issue of concern in most developing countries of the world today, especially in sub-Saharan Africa, where a large number of young girls do not attend school. According to UNICEF (2007), as cited by Grace (2010), the global figure for out-of-school children is estimated to be 121 million, out of which 65 million (approximately 53.8\%) were girls and over 80 percent of these girls live in sub-Saharan Africa.

Primary school completion rates in Africa have been the lowest in the world and this remains a concern as half of the world's out-of-school children (OOSC) are concentrated in 15 countries, eight of which are in subSaharan Africa (Ibrahim, 2012).

In sub-Saharan Africa, the number of girls out of school each year has risen from 20 million in 1990 to 24million in 2002 (Offorma, 2009).

Also, according to Goodluck (2011), Nigeria has 9 million (37\%) out-of-school children, which is more than 0ne-third of its primary school age children and this is the highest in Africa. Nigeria grapples with increasing number of out-of-school children annually. This trend varies from zone to zone. For instance, in South Eastern Nigeria, which is dominated by the people of Igbo ethnic group, there is however low boy-child enrolment in school as compared to girls. This is because the boy-children are sent for apprenticeship in trading which is the dominant occupation of the people. The opposite is the case in Northern Nigeria where there is low girl-child education as compared to boys. Nigeria is among the West African countries that have the highest number of girls that are out of school, and more than $75 \%$ of the 3.4 million children out of school are girls (UNICEF, 2007). The National School Census (NSC) (2006), also revealed a net enrolment ration of $80.6 \%$ suggesting that a substantial proportion (19\%) of primary school age population between 6-11years are not enrolled in primary schools nationwide, and this represents about 5million of Nigerian children of the age bracket of 6-11years old that do not have access to primary education.

In the Northern part of Nigeria, which comprises three geo-political zones: the North East, North Central and North West. The north Central shows an improvement over others, these zones cannot boast of 
appreciable number of girls' enrolment at primary and secondary schools level, not to talk of tertiary level of education, as compared to boys' enrolment.

Statistics from the Federal office of statistics (2004) shows that, literate women constituted only $20 \%$ from the North -West, $20 \%$ North- East, and $45 \%$ from the North Central. This indicates the levels of backwardness of women as compared to men in Northern Nigeria. The National School Census (2006) reported that the number of children out of school in Northern Nigeria is particularly high and the proportion of girls to boys in school ranges from 1 girl to 2 boys and even 1 girl to 3 boys in some states. The education of girls in the northern cluster has always been a thorny and unresolved issue. Typically, girl-child education in northern states follows a specific pattern which ends with the girls being denied from the system, the chances to attend primary school or further their education beyond primary school. Enejere (1991) avers that gender inequality especially in Northern Nigeria is promoted by religious and communal customs, which has grave consequences for both the individual and the society making her a dysfunctional member of the society.

So many factors have been reported to be responsible for low enrolment of girls in schools in northern Nigeria. Mukhtar et al. (2011) identified religious misinterpretation, cultural practice, poverty, early marriage, illiteracy, inadequate school infrastructure as some of the factors militating against girl-child education. To majority of the parents, girl-child education is less important because no matter what level of education the girl attains, their hope is to see the girl-child get married. To some parents, western type of education is termed to be a way of negative transformation and initiation of an individual into materialism, promiscuity and inculcation of western cultural ideologies.

With almost $70 \%$ of the Nigerian population living below the poverty line, girls are often sent to hawk wares on the streets. Barriers to girl-child education in Nigeria especially in the north have been identified as poverty, early marriage, cultural and religious misconceptions as well as teenage pregnancy (Williams, 1960).

Kebbi State, like every other state in Northern Nigeria, grapples with low girl-child enrolment in school and colleges. This has become a major source of concern and worries to Kebbi State Government, Nongovernmental organizations and other stakeholders in the educational sector. This ugly trend has, over the years, continued to deepen the educational and economic inequality between the men and women in the state.

Furthermore, the rural areas in Kebbi State are the worst hit; they do not only lack schools but also see no need for enrolment of the girl-child. This dehumanizing ignorance has continued to plague most rural dwellers in the north from year to year. It is really a pathetic situation where people, from generation to generation, fail to realize that they could be of any use not only to themselves but to the larger society.

Kalgo Local Government Area, unlike any other local government in Kebbi state, has its own major challenges of providing basic education to its citizenry especially in the rural areas and particularly to the girlchild. Its inability to provide adequate basic education for the rural population has continued to heighten the inequality between the male and female children enrolment in schools.

That does not mean that, the problems of girl-child education in Kalgo Local Government Area are not insurmountable. It only needs the political will on the part of the Kebbi State Government, Kalgo Local Government Council and other stakeholders like Religious leaders, traditional rulers, parents and NonGovernmental organizations to play critical roles in arresting the situation.

\section{Purpose of the Study}

This research work sought to identify the major problems bedeviling girl-child education or responsible for low girl-child enrolment in schools in Kalgo Local Government Area of Kebbi state with a view of proffering solutions to them.

The research work also hoped to identify factors that are peculiar to Kalgo Local Government Area of Kebbi State, so as to present an in-depth analysis on the infrastructural, political, economic, demographical, religious and cultural issues as they affect the education of the girl-child in Kalgo Local Government Area.

\section{Statement of the Problem}

Education is meant for all; in fact, it is the fundamental human right of every child whether boy or girl, able or disabled to acquire the basic education. There should therefore, be no discrimination as to who goes to school and who does not, hence education recognizes and helps to unlock the potentials in every child.

Low enrolment of the girl-child in school is widening the educational and economic gap between the men and the women folks in Northern Nigeria and Kebbi in particular. Addressing the problems and challenges of girl-child education in Kalgo LGA has become necessary in view of not only the ignorance of rural dwellers on the importance of education, but also the dehumanizing practice of keeping the girl-child out of school.

\section{Significance of Study}

This study will enable the stakeholders in the area of education in kebbi state to address the problems of girl-child. It is also hoped that the KalgoLocal Education Authority (LEA) and Kebbi State Ministry of 
Education will find this work most useful in planning their educational budget so that the rural population of Kalgo LGA is put on the pedestal of equal and adequate educational opportunities for all citizens.

\section{Research Questions}

This study hoped to provide answers to the following research questions:

1. To what extent do girl-children enroll in primary schools in Kalgo L.G.A?

2. To what extent do girl-children enroll in secondary schools in Kalgo L.G.A?

\section{Research Design}

\section{Methodology}

For the purpose of this study, the descriptive research design was adopted, which was used to observe or explain phenomenon without manipulating any variable.

\section{Area of Study}

This research work was carried out in Kalgo Local Government Area of Kebbi State. Kalgo LGA was created in the military edict of the Federal Military Government of Nigeria in 1996, with its headquater in the town of kalgo. It has an area of $1,173 \mathrm{~km}^{2}$, which is part of the Sokoto plains lying $300 \mathrm{~m}$ above sea level.

At present, Kalgo LGA has fourteen (14) communities/villages. They are:

Badariya, Banganna, Dangoma, Diggi, Etene, Gayi, Kalgo, Kuka, Kutukullu, Magarza, Mutubari, Nayilwa, Wurogauri, and Zuguru.

\section{Population and Sample}

The population for this study comprise of all the four (4) secondary schools and fifty one (51) primary schools located within Kalgo LGA. Meanwhile, a sample of two (2) secondary schools and fourteen (14) primary schools was randomly selected from the population. Meanwhile, fourteen (14) representative primary schools with the highest number of pupils enrollments, were selected from each sampled community in the fourteen (14) villages/ communities within the local government area, which were the Model Primary Schools, (MPS) established by the state government.

\section{Instrumentation}

The main instruments used for data collection in the course of this study were,the checklist, Inventory and Oral interviews.

\section{Data Collection and Analysis}

Data for this research was basically archival, collected through the Checklist/Inventory and Oral interviews, while the analysis was done using simple descriptive statistics and tables.

\section{Results}

\section{Results And Discussion}

Research question 1.

To what extent do girl-children enrol in primary schools in Kalgo L.G.A ?

Table1: Percentage enrolment of girls for the year 2013/2014 academic session in the representative Model primary schools.

\begin{tabular}{|l|l|l|l|l|l|}
\hline S/N & Name of primary school & $\begin{array}{l}\text { Number } \\
\text { males }\end{array}$ & $\begin{array}{l}\text { Number } \\
\text { females }\end{array}$ & $\begin{array}{l}\text { Total } \\
\text { of pupils }\end{array}$ & $\begin{array}{l}\text { of enrolment of } \\
\text { females }\end{array}$ \\
\hline 1 & Badariya Model Primary School & 85 & 24 & 110 & $23 \%$ \\
\hline 2 & Banganna Model Primary School & 121 & 92 & 213 & $43 \%$ \\
\hline 3 & Dangoma Model Primary School & 217 & 52 & 269 & $19 \%$ \\
\hline 4 & Diggi Model Primary School & 258 & 127 & 385 & $33 \%$ \\
\hline 5 & Etene Model Primary School & 169 & 45 & 214 & $21 \%$ \\
\hline 6 & Gayi Model Primary School & 155 & 82 & 237 & $35 \%$ \\
\hline 7 & Kalgo Model Primary School & 335 & 306 & 641 & $48 \%$ \\
\hline 8 & Kuka Model Primary School & 183 & 256 & $29 \%$ \\
\hline 9 & Kutukullu Model Primary School & 153 & 198 & $23 \%$ \\
\hline 10 & Magarza Model Primary School & 167 & 45 & 204 & $18 \%$ \\
\hline 11 & Mutubari Model Primary School & 129 & 37 & 177 & $27 \%$ \\
\hline 12 & Nayilwa Model Primary School & 137 & 48 & 214 & $36 \%$ \\
\hline 13 & Wurogauri Model Primary School & 136 & 77 & 206 \\
\hline 14 & Zuguru Model Primary School & 119 & 70 & 170 \\
\hline
\end{tabular}

Source: LEA Office, Kalgo (2014). 
Table 1 shows the grand percentage enrollment of girls in Kalgo local government area, in the year 2013/2014 academic session to be $32 \%$. This indicates that there is a poor state of enrolment.

Research question 2.

To what extent do girl-children enrol in secondary schools in Kalgo L.G.A ?

Table 2: Percentage enrolment of girls in Government Day Secondary School Diggi for the year 2013/2014 academic session

\begin{tabular}{|l|l|l|l|l|l|}
\hline S/N & Class & Number of boys & Number of girls & Total & \% enrolment of girls \\
\hline 1 & JSS 1 & 207 & 140 & 347 & $40 \%$ \\
\hline 2 & JSS 2 & 200 & 130 & 330 & $39 \%$ \\
\hline 3 & JSS 3 & 173 & 105 & 278 & $38 \%$ \\
\hline 4 & SSS 1 & 161 & 71 & 232 & $31 \%$ \\
\hline 5 & SSS 2 & 206 & 65 & 271 & $24 \%$ \\
\hline 6 & SSS 3 & 217 & 55 & 272 & $20 \%$ \\
\hline & Total & $\mathbf{1 1 6 4}$ & $\mathbf{5 6 6}$ & $\mathbf{1 7 3 0}$ & $\mathbf{3 3 \%}$ \\
\hline
\end{tabular}

Source: Government Day Secondary School (GDSS), Diggi.

Table 2 has clearly revealed the state of enrollment of girl-children in Government day secondary school Diggi to be 33\%. This is followed by the higher number of boys enrollment which is 1164 at against 566 for that of girls.

Research question 2.

To what extent do girl-children enrol in secondary school in kalgo L.G.A ?

Table 3: Percentage enrolment of girls in Government Day Secondary School Kalgo for the year 2013/2014 academic session

\begin{tabular}{|l|l|l|l|l|l|}
\hline S/N & Class & Number of boys & Number of girls & Total & \% enrolment of girls \\
\hline 1 & JSS 1 & 175 & 141 & 316 & $45 \%$ \\
\hline 2 & JSS 2 & 177 & 135 & 312 & $43 \%$ \\
\hline 3 & JSS 3 & 150 & 111 & 261 & $43 \%$ \\
\hline 4 & SSS 1 & 188 & 72 & 260 & $28 \%$ \\
\hline 5 & SSS 2 & 175 & 67 & 242 & $28 \%$ \\
\hline 6 & SSS 3 & 243 & 60 & 303 & $20 \%$ \\
\hline & Total & $\mathbf{1 1 0 8}$ & $\mathbf{5 8 6}$ & $\mathbf{1 6 9 4}$ & $\mathbf{3 5 \%}$ \\
\hline
\end{tabular}

Source: Government Day Secondary School (GDSS), Kalgo

Table 3, shows that out of $100 \%$ girl-children enrollment rate required from the Government Day secondary school Kalgo in the year 2013/2014 academic session, the average per centage enrollment of girls was only found to be $35 \%$. This also shows a low percentage enrollment.

\section{Discussion of Findings}

The findings obtained from table 1 shows the percentage enrollment of girls in the year 2013/2014 academic session from the sampled primary schools as: Badariya Model Primary School 23\%, Banganna Model Primary School 43\%, Dangoma Model Primary School 19\%, Diggi Model Primary School 33\%, Etene Model Primary School 21\%, Gayi Model Primary School 35\%, Kalgo Model Primary School 48\%, Kuka Model Primary School 29\%, Kutukullu Model Primary School 23\%, Magarza Model Primary School 18\%, Mutubari Model Primary School 27\%, Nayilwa Model Primary School 36\%, Wurogauri Model Primary School 34\%, and Zuguru Model Primary School 30\%, there by, bringing the average percentage enrollment to be $32 \%$.

Also, from the overall result of the percentage enrollment of girls in the two sampled secondary schools, Government Day secondary school Diggi and Government Day secondary school Kalgo, the average percentage enrollment for the 2013/2014 academic year from JSS 1 to SSS 3, was found to be $32 \%$ and $35 \%$ respectively in Kalgo local government area, which shows a low level of enrollment and commitment.

These findings are in line with the earlier findings of Ibrahim (2012), who says that primarary school completion in Africa have been the lowest in the world. Similarly, Offorma (2011) and Goodluck (2011) also affirms that the number of girls out of school each year in sub-saharan Africa is on the increase on yearly basis, and that Nigeria grapples with increasing number of out- of- school children, annually.most especially girls.

\section{Recommendations}

In view of the various problems affecting girl-child education in Kalgo LGA as unraveled, the following recommendations among other things were put forward to help tackle and address those problems. 
1) Government at all levels should make concerted effort to alleviate poverty at the grass root, as this will undoubtedly overcome the challenge of not sending the girl-children to school by parents for reason of poverty.

2) Another responsibility that government should take up so as to tackle this menace is to provide free, compulsory primary and secondary education in all the fourteen (14) villages in Kalgo LGA. Schools should be built, well-staffed and equipped to provide quality education so that the children can compete favorably with their counterparts from other parts of the country.

3) Parents should be enlightened to encourage the girl-child to acquire basic education, at least, that will make her self-reliant and to secure a better future for herself. Governments, Non-Governmental Organizations, Religious leaders and traditional rulers have a major role to play in leading these awareness and enlightenment campaigns on not only the importance of western education for the girl-child but also on the need to discard the various cultural and religious misconceptions that have militated against girl-child education in Northern Nigeria over the years.

4) Governments should also make a promulgation by rising the age of marriage for girls to at least twenty (20) years of age or above.

\section{Conclusion}

Barriers to girl-child education in Nigeria especially in the north have been tied to several factors such as poverty, early marriage, cultural and religious misconceptions or misinterpretations, as well as teenage pregnancy

Various studies have also been enumerated which identified religious misinterpretations, cultural practices and economic factors as issues militating against girl-child education in Nigeria especially in the north (Nwagwu, 1976).

It has also been revealed that the inability of parents to provide adequate and basic education for their girl-children by sending them to school which is their sole responsibility, either as a result of illiteracy, poverty, cultural or religious misconceptions has created inequality between the male and female children enrolment in schools and the local government area at large.

\section{References}

[1]. Ada, N.A. (1992). The Paradox of Equality of Education Opportunities for All Citizens in Nigeria and Challenges of Rural Transformation. Journal of the Arts and Humanities, (2) 48-56.

[2]. Enejere, E. (1991). Women and Political Education. Enugu: Malthouse Press Ltd., Pp 44-51.

[3]. Federal Office of Statistics (2004).The Nigerian Statistical Fact Sheet on Economic and Social Development.NationalBureau of Statistics, ISBN 978-34144-0-2.

[4]. GDSS, Kalgo (2012). Enrolment and Admission Register, (from the Office of the Principal, Government Day Secondary School, Kalgo).

[5]. Grace, E.T. (2010). Girls Child Education: Rising to challenge. African Journal of Reproductive Health, $14(3)$ : 107.

[6]. LEA Office, Kalgo (2012).Enrolment of Boy and Girl Children in Kalgo LGA. (From the Research, Planning and Statistics Office, Kalgo Local Education Authority, Kalgo).

[7]. Ibrahim, M.O. (2012). African Youths Fulfilling their Potentials.http://www.moibrahimfoundation.org.Accessed on December 13 ${ }^{\text {th }}$, 2012 .

[8]. National School Census (2006).Federal Ministry of Education Statistics and Planning Unit, National Policy on Education (NPE, 2004).

[9]. Nigeria UNICEF Country Office (2007).Girls Education.http://www.unicef.org/wcaro-nigeria-factsheets-girlseducation.pdf.

[10]. Nwangwu, N.A. (1976). Universal Primary Education: Issues Prospects and Problems. Benin: Ethiope Publishers, Pp 13.

[11]. Offorma, G.C (2009).Girl-child Education in Africa. Keynote Address Presented at the Conference of the University Women of Africa Held in Lagos, Nigeria, 16th-19 ${ }^{\text {th }}$ July, 2009.

[12]. Williams, D.H. (1960). A Short Survey of Education in Northern Nigeria. Kaduna: Government Press, Northern Region. 